\title{
Serological detection of bovine leukemia virus in slaughterhouse workers from San Nicolás de los Garza, Nuevo León, México
}

\author{
Diana E. Zamora-Avila ${ }^{1 *}$, Pablo Zapata-Benavides ${ }^{2}$, Sibilina Cedillo-Rosales ${ }^{1}$, Ramiro Avalos- \\ Ramírez ${ }^{1}$, Juan J. Zarate-Ramos ${ }^{1}$, Víctor Riojas-Valdés ${ }^{1}$, José A. Salinas-Meléndez ${ }^{1}$, Lydia \\ Rivera-Morales ${ }^{2}$ and Laura Trejo-Avila ${ }^{2}$ \\ ${ }^{1}$ Universidad Autónoma de Nuevo León, UANL, Fac. de Medicina Veterinaria y Zootecnia, Campus de Ciencias \\ Agropecuarias. Escobedo, N.L. C.P. 66050, México. \\ ${ }^{2}$ Universidad Autónoma de Nuevo León, UANL, Fac. de Ciencias Biológicas, Departamento de Microbiología e \\ Inmunología. Ciudad Universitaria. Aptdo. postal 46 "F". San Nicolás de los Garza, N.L. CP. 66450, México.
}

Accepted 10 May, 2013

\begin{abstract}
Bovine leukemia virus (BLV) is a retrovirus that primarily infects older dairy cattle, but many studies have shown that the BLV host range is broader than previously reported. Monitoring risk groups, such as slaughterhouse workers, is important to determine if BLV can infect humans and cause disease.The aim of this study was to determine whether slaughterhouse workers can be infected with the BLV. We also determined the seroprevalence of human T-lymphotropic virus (HTLV-I/II) and human immunodeficiency virus (HIV) to rule out cross-reactivity. This study included 28 blood samples from 28 slaughterhouse workers from a cattle butchery in San Nicolás de los Garza, Nuevo León, México. BLV was analyzed using an agar gel immunodiffusion test (IDAG), Western blotting, and PCR. The seroprevalence of HTLV-I/II and HIV were determined with passive agglutination and enzyme-linked immunosorbent assay (ELISA), respectively. Two samples (7.1\%) were positive for BLV with IDAG, and this was confirmed with Western blotting. All samples were HTLV-I/II negative, and only one worker was HIV positive but BLV negative. These results suggest that humans are not necessarily infected with $B L V$, but rather seropositivity results from an abortive infection.
\end{abstract}

Key words: Bovine leukemia virus (BLV), slaughterhouse workers, México, agar gel immunodiffusion test (IDAG).

\section{INTRODUCTION}

Bovine leukemia virus (BLV) belongs to a family of oncogenic retroviruses that includes human $\mathrm{T}$ cell leukemia virus type I and II (HTLV-I and II) and simian Tcell leukemia virus (Hajj et al., 2012; Rodríguez et al., 2011). These retroviruses share a common genomic organization (Sagata et al., 1985) and are associated with lymphoid neoplasia and/or progressive myelopathies. BLV is the etiologic agent of enzootic bovine leukosis, which is the most common neoplastic disease in cattle. In most cases, BLV infection remains clinically silent, and infected animals are referred to as aleukemic; alternatively, BLV can emerge as a persistent lymphocytosis. The natural mode of transmission of BLV in cattle occurs from infected lymphocytes of one animal to another, horizontally or vertically (Hajj et al., 2012; Rodríguez et al., 2011). Experimentally, BLV can infect 
other animals such as goats, sheep, rabbits, water buffalo and some cell lines from other animal species including humans (Altanerova et al., 1990; Onuma et al., 1990; Meas et al., 2000). The possibility that humans may be susceptible to BLV has been examined in several ways. Slavikova et al. (1987) reported reverse transcriptase-mediated BLV provirus integration into the DNA of different infected human cells such as myeloma ARH77 and myeloid K562 cells. In addition, BLV antibodies have been detected in sera from leukemic patients (Cereda et al., 1984). Buehring et al. (2003) used immunoblotting to test the sera of 257 humans for antibodies of four isotypes ( $\lg G 1, \lg M, \lg A$, and $\lg G 4)$ to the BLV capsid antigen (p24). They detected at least one antibody isotype that was reactive to BLV in $74 \%$ of the human serum samples tested. Recently, Nikbakht et al. (2010) reported the genomic detection of BLV in human samples using nested PCR. In addition, Lee et al. (2005) investigated the presence of BLV in leukemia and lung cancer patients in Koreans and founded BLV infection in human cells with PCR but negative results in patients. These results suggest that antibodies that are reactive to the BLV capsid antigen may serve as a biomarker for exposure to BLV and that this exposure may be widespread. The results do not necessarily mean that humans are actually infected with BLV; the antibodies could be a response to heat-denatured BLV antigens consumed in food. The results do, however, suggest that further studies on this topic may be important. The purpose of the present study was to determine if a high-risk group such as slaughterhouse workers can be infected with $B L V$ in a region with high $B L V$ prevalence in cattle.

\section{MATERIALS AND METHODS}

\section{Sample collection}

A total of 28 blood samples from 28 slaughterhouse workers from a butchery in San Nicolás de los Garza, Nuevo León, México were collected with and without anticoagulant. The sera were obtained by centrifugation at $2000 \mathrm{rpm}$ for $10 \mathrm{~min}$ and stored at $20^{\circ} \mathrm{C}$ for later determinations.

The cell line FLK-BLV (Fetal Lamb Kidney infected with BLV) was used as a positive control. It was obtained from the American Type Culture Collection (ATCC, Manassas, VA, USA) and was cultured and maintained in Dulbecco's modified Eagle's medium (DMEM/F-12) (Life Technologies, Invitrogen, Burlington, Ontario, Canada) supplemented with $10 \%$ fetal bovine serum, $100 \mathrm{U} / \mathrm{ml}$ penicillin, and $100 \mathrm{~g} / \mathrm{ml}$ streptomycin (Gibco, Grand Island, NY, USA). Cells were incubated in a humidified chamber at $37^{\circ} \mathrm{C}$ in an atmosphere of $95 \% \mathrm{O}_{2}$ and $5 \% \mathrm{CO}_{2}$.

\section{Isolation and culture of lymphocytes}

$7 \mathrm{ml}$ of blood was collected in tubes with EDTA and centrifuged at $1500 \mathrm{rpm}$ for $30 \mathrm{~min}$. The buffy coat was removed and resuspended in $2 \mathrm{ml}$ sterile saline solution. The suspension was deposited in $4 \mathrm{ml}$ Ficoll-paque (Sigma Chemical Co., St. Louis, MO, USA) and centrifuged at $2000 \mathrm{rpm}$ for $30 \mathrm{~min}$. The mononuclear cells at the interface were aspirated and suspended in $10 \mathrm{ml}$ saline solution. These peripheral blood mononuclear cells were washed two times with $10 \mathrm{ml}$ sterile phosphate-buffered saline (PBS).

\section{Antigen}

The antigen was obtained from FLK-BLV cells described above. Culture fluid was clarified by centrifugation at $5000 \mathrm{rpm}$ for $10 \mathrm{~min}$. Protein was precipitated with $33 \%$ ammonium sulfate for $72 \mathrm{~h}$ at $4^{\circ} \mathrm{C}$ and centrifuged at $2500 \mathrm{rpm}$ for $15 \mathrm{~min}$. The precipitate was resuspended in PBS to approximately one-tenth the original volume and dialyzed for $24 \mathrm{~h}$ against PBS. The fluid was passed through a column containing A-Sepharose. The column was then washed with PBS, and the glycoprotein was eluted with $0.1 \mathrm{M}$ alpha-methyl-Dmannosidase.

\section{Serological screening tests}

The serum samples were tested for BLV antibodies using the agar gel immunodiffusion (IDAG) test at $0.8 \%$ using the glycoprotein antigen Gp51 from the FLK-BLV cells according to the method of Miller and Van Der Maaten (1977). Screening for HTLV-I/II antibodies was performed using a gelatin-particle assay agglutination test (PA; Serodia HTLV-I kit, Fujirebio, Tokyo, Japan). HIV antibody screening was performed using a Vironostika HIV-I Microelisa system (Organon Teknika, NC, USA) according to the manufacturer's instructions.

\section{Western blot}

The Western blot test was used as a confirmatory test for BLV. FLK-BLV cells were plated at $1 \times 10^{6}$ cells $/ 25-\mathrm{cm}^{2}$ flask in $5 \mathrm{ml}$ DMEM/F-12 supplemented with $10 \%$ fetal bovine serum and incubated overnight. The harvested cells were lysed with $100 \mu \mathrm{l}$ lysis buffer ( $1 \%$ Triton, $150 \mathrm{mmol} / \mathrm{l} \mathrm{NaCl}, 25 \mathrm{mmol} / \mathrm{l}$ Tris, $\mathrm{pH} 7.6$ ), and the protein concentration was measured using a DC Protein Assay kit (Bio-Rad, Hercules, CA, USA). Approximately $50 \mu \mathrm{g}$ of each protein sample was separated using $12 \%$ sodium dodecyl sulfate (SDS) polyacrylamide gel electrophoresis and analyzed with Western blotting using the workers sera problem sera (1:100) as a primary antibody and peroxidase-labeled anti-bovine or anti-human antibody as the secondary antibody (1:100) (Sigma, St Louis, Missouri, USA). Proteins were visualized with the substrate diaminobenzidine and $0.05 \%$ hydrogen peroxide.

\section{DNA extraction}

DNA was extracted from lymphocytes cultivated as described by Curtis and Kersey (1988). Briefly, $2 \times 10^{6}$ cells were transferred to a $1.5-\mathrm{ml}$ eppendorf tube and washed with $1 \mathrm{ml}$ cold PBS. The cells were resuspended in $200 \mu$ lysis buffer $(10 \mathrm{mM}$ Tris- $\mathrm{HCl}, \mathrm{pH} 8.0$, $100 \mathrm{mM} \mathrm{NaCl}, 1 \mathrm{mM}$ EDTA) containing $10 \mu \mathrm{l}$ proteinase $\mathrm{K}(100$ $\mu \mathrm{g} / \mathrm{ml}), 50 \mu \mathrm{I}$ EDTA $(0.5 \mathrm{mM})$, and $50 \mu \mathrm{l} 20 \%$ SDS, and incubation was carried out at $60^{\circ} \mathrm{C}$ for $1 \mathrm{~h}$. After digestion with proteinase $\mathrm{K}$, one-tenth volume sodium acetate was added followed by one extraction with a 1:1 volume of phenol-chloroform and one extraction with chloroform-isoamyl alcohol. The DNA was precipitated with 2.5 volumes of cold ethanol and resuspended in $20 \mu \mathrm{l}$ TE buffer (10 $\mathrm{mM}$ Tris- $\mathrm{HCl}, \mathrm{pH}$ 8.0, 1 mM EDTA).

\section{PCR amplification}

BLV PCR reactions were carried out in a total volume of $50 \mu \mathrm{l}$ 


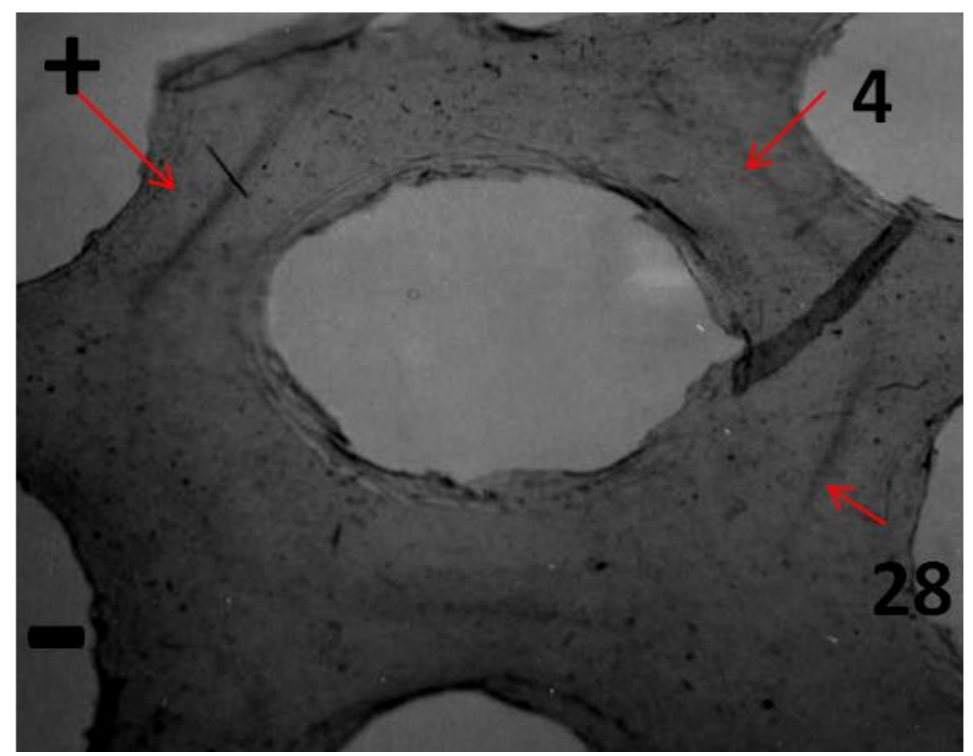

Figure 1. Agar Gel Immunodiffusion (IDAG) for BLV. Two samples that were positive for BLV antibodies (number 4 and 28) are shown. +, positive control; -, negative control.

containing $4 \mu \mathrm{I}$ DNA, $0.2 \mathrm{mM}$ (each) deoxynucleoside triphosphate

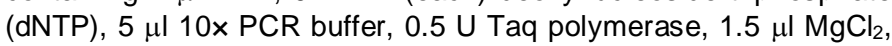
and $100 \mu \mathrm{M}$ BLV gag gene primers (sense and antisense) to amplify a fragment of $226 \mathrm{bp}$. PCR primers and the thermal profile were done as described by Murtaugh et al. (1991). PCR products were subjected to electrophoresis on $1.2 \%$ agarose gels, and the products were visualized with ethidium bromide and photographed under UV light.

\section{RESULTS AND DISCUSSION}

Twenty-eight (28) slaughterhouse workers were included in this study, with an average age of 42.6 years and a range of duration of working at the butchery of 6 months to 30 years (average 13.4 years).

Using the serological IDAG test for BLV, we found two samples $(7.1 \%)$ that were positive for BLV antibodies; sample 4 was from a 39-year-old worker with nine years of service, and sample 28 was from a 58-year-old worker with 20 years of service (Figure 1). To confirm the presence of BLV antibodies, Western blotting was carried out, and this corroborated the positive results (Figure 2).

PCR amplification of the gag gene to identify the BLV provirus was negative in all samples, including the two samples that were positive for BLV antibodies; only the control FLK-BLV cell line was positive as expected (Figure 3).

To rule out cross-reactivity, we assayed for HTLV-I/II and HIV antibodies. The two BLV-positive samples were negative for these retroviruses, indicating specificity for BLV. However, one sample (number 18 from a 40-yearold worker with 2 years of service) was positive for HIV but negative for HTLV-I/II and BLV (Figure 4).
The results of the 28 samples analyzed for all three retroviruses (BLV, HTLV-I/II, and HIV) are summarized in Table 1.

BLV is a lymphotropic retrovirus that causes lymphoproliferative disorders, and under natural conditions, affects only cattle (Burny et al., 1985; Ghysdael et al., 1984). Experimentally, BLV has been shown to infect other animal species including primates as well as human cells (Wyatt et al., 1989; Johnson et al., 1994; Altanerova $V$ et al., 1990). Moreover, workers handling infected meat in a food store have a 3 -fold increased risk of contracting myeloid leukemia and non-Hodgkin's lymphoma as well as lung cancer (Johnson et al., 1986, 1995).

Whether BLV can infect and induce neoplasias in humans has long been controversial. In this study, we analyzed 28 samples from slaughterhouse workers who have potential occupational exposure because they have been in contact with blood and body fluids of cattle for over 10 years in an endemic area with a high prevalence (more than $40 \%$ ) of BLV in dairy cattle (Northeastern Mexico) (Zapata-Benavides P, University Autonomy of Nuevo Leon, Mexico, personal communication). We found two samples that were positive for BLV antibodies with the IDAG assay; however, these same samples were negative for the BLV provirus with PCR.

The presence of BLV antibodies in serum has been reported by some authors (Nikbakht et al., 2010; Buehring et al., 2003; Johnson et al., 1995). However, this detection does not guarantee viral infection. Buehring et al. (2003) reported that humans are not necessarily infected with the virus; the antibodies may be a response to the consumption of heat-denatured proteins from meat products. In another study, Malivanova et al. (1990) 


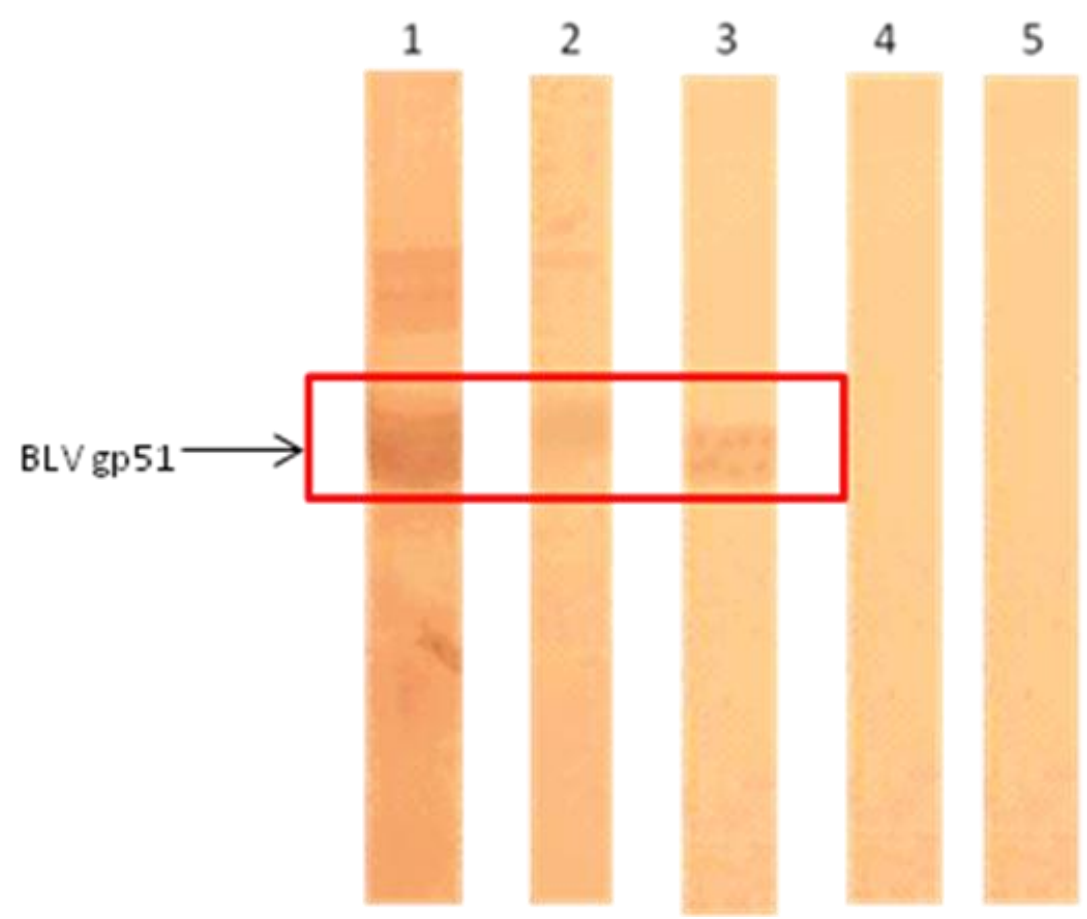

Figure 2. Western blot for BLV. Two BLV-positive samples (number 4 and 28) as seen with IDAG were analyzed with Western blotting as a confirmatory test. Lane 1, Positive control (FLK-BLV cells); Lanes 2 and 3, Samples 4 and 28; respectively. Lane 4, Sample 18; which was positive for HIV with ELISA but negative for BLV. Lane 5, Negative control.

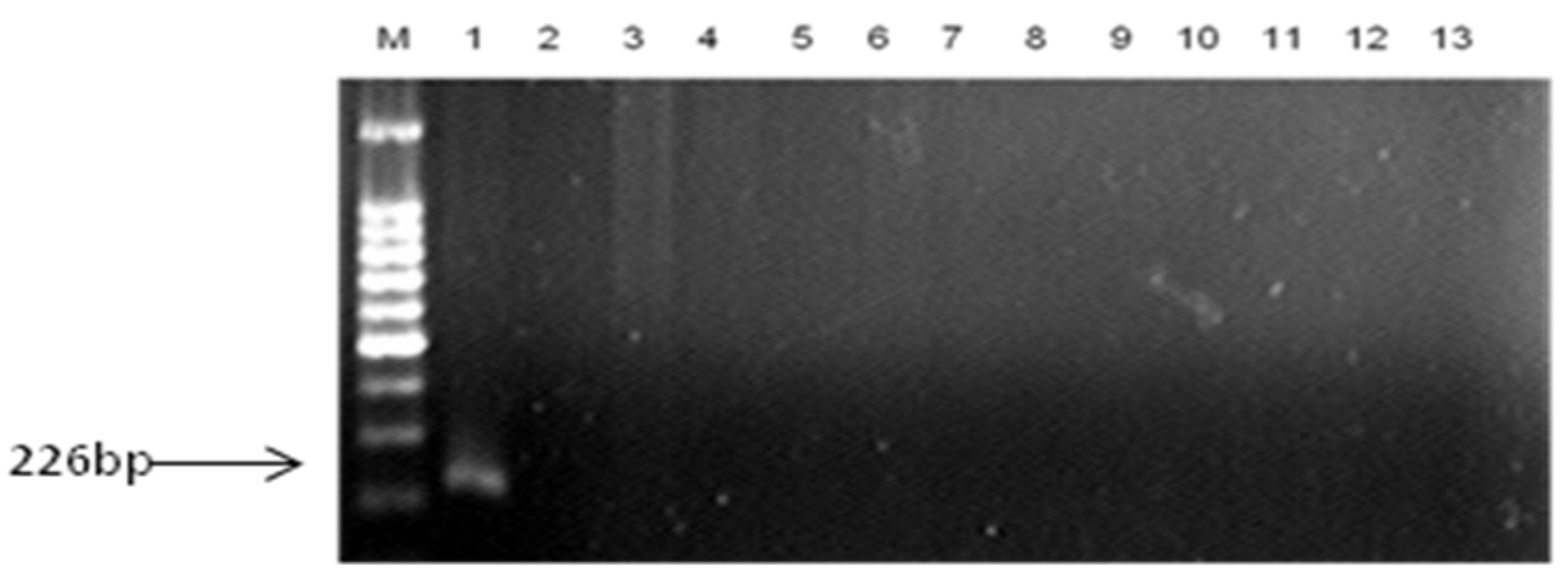

Figure 3. PCR for the BLV gag gene in the DNA of peripheral blood lymphocytes of slaughterhouse workers. M, Molecular weight marker $100 \mathrm{bp}$; lane 1, positive control FLK-BLV cell line; lanes 2 to 12, samples of slaughterhouse workers that were negative; lane 13, negative control.

reported the presence of antibodies in female patients with benign and malignant mammary tumors. Lee et al. (2005) did not find proviral DNA in patients with leukemia and lung cancer in Korea. However, the majority of PCR assays are based on a single assay, but fewer than eight genomic copies of the provirus can be detected in a background of 2 million negative lymphocytes using nested PCR (Ballagi-Pordany et al., 1992). In this way, Nikbakht et al. (2010) detected BLV proviruses in human samples using nested PCR and confirmed the results with Southern blot analysis.

Maruyama et al. (1989) reported that human sera that are ELISA positive for HTLV-I react with p12 and p24 of BLV. In this study, to rule out cross-reactivity with other 


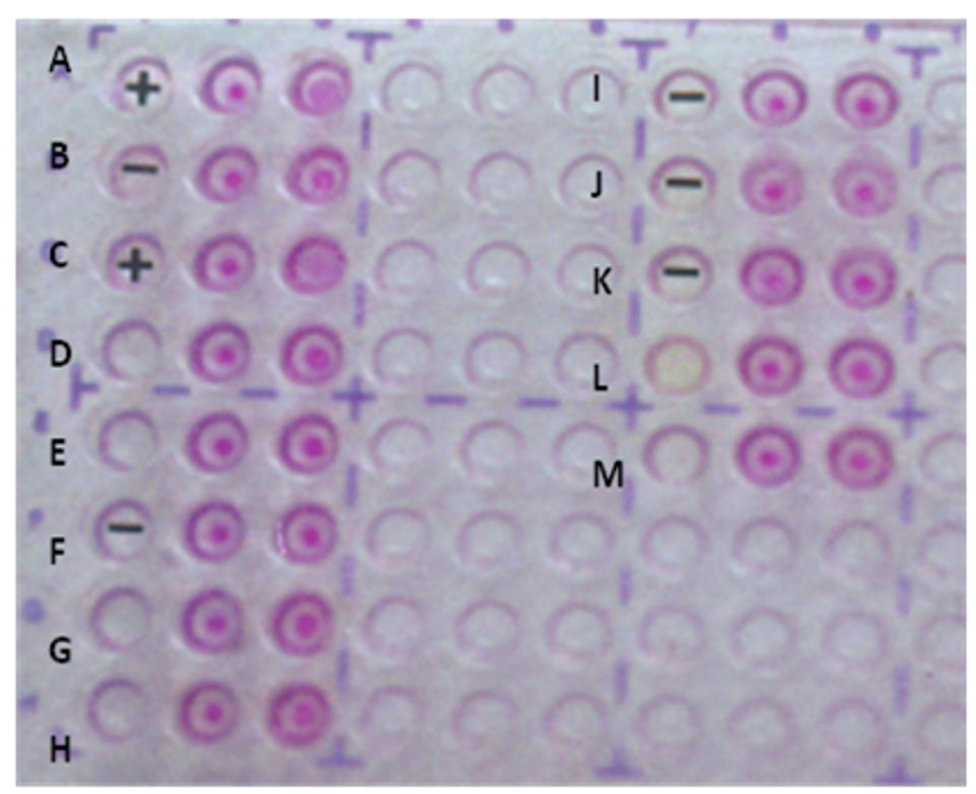

Figure 4. Gelatin-particle assay agglutination test for HTLV-I/II. A, Positive HTLV patient serum; B, Kit negative control; $c$, kit positive control; D-M, serum samples from slaughterhouse workers.

Table 1. The results from the 28 samples analyzed with the different methodologies for all three retroviruses (BLV, HTLV, and HIV).

\begin{tabular}{|c|c|c|c|c|}
\hline \multirow{2}{*}{ Sample } & \multirow{2}{*}{$\begin{array}{l}\text { BLV } \\
\text { IDAG }\end{array}$} & \multicolumn{2}{|c|}{ HTLV } & \multirow{2}{*}{$\begin{array}{l}\text { HIV } \\
\text { ELISA }\end{array}$} \\
\hline & & PCR & PA & \\
\hline FLK-BLV cell line & - & + & - & - \\
\hline Positive HTLV serum & - & - & + & - \\
\hline Positive HIV serum & - & - & - & + \\
\hline 1 & - & - & - & - \\
\hline 2 & - & - & - & - \\
\hline 3 & - & - & - & - \\
\hline 4 & + & - & - & - \\
\hline 5 & - & - & - & - \\
\hline 6 & - & - & - & - \\
\hline 7 & - & - & - & - \\
\hline 8 & - & - & - & - \\
\hline 9 & - & - & - & - \\
\hline 10 & - & - & - & - \\
\hline 11 & - & - & - & - \\
\hline 12 & - & - & - & - \\
\hline 13 & - & - & - & - \\
\hline 14 & - & - & - & - \\
\hline 15 & - & - & - & - \\
\hline 16 & - & - & - & - \\
\hline 17 & - & - & - & - \\
\hline 18 & - & - & - & + \\
\hline 19 & - & - & - & - \\
\hline 20 & - & - & - & - \\
\hline 21 & - & - & - & - \\
\hline 22 & - & - & - & - \\
\hline
\end{tabular}


Table 1. Contd

\begin{tabular}{lllll}
\hline 23 & - & - & - & - \\
24 & - & - & - & - \\
25 & - & - & - & - \\
26 & - & - & - & - \\
27 & - & - & - & - \\
28 & + & - & - & - \\
\hline
\end{tabular}

Samples 4 and 28 were positive for BLV with IDAG, but were negative with PCR; these samples were also negative for HTLV and HIV. Only one sample (18) was positive for HIV, but it was BLV negative. BLV, bovine leukemia virus; HTLV, human T-lymphotropic virus; HIV, human immunodeficiency virus; IDAG, agar gel immunodiffusion test; PCR, polymerase chain reaction; PA, gelatin-particle assay agglutination test; ELISA, enzyme-linked immunosorbent assay.

retroviruses such as HTLV I/II and HIV, serological tests for these retroviruses were included, and the results for HTLV were negative. Similar results were obtained by Zapata et al. (1996) who reported that HTLV is not circulating in Northeastern Mexico or its incidence is so low that is not detected. For HIV, only one sample (3.6\%) was positive, but this sample was negative for BLV. Thus, the antibodies we found were specific for BLV.

In the samples that were positive with IDAG, one of the following conditions is likely: 1) Constant exposure without infection may have occurred, causing an awakened immune response. However, the virus was not able to integrate into the human genome. 2) The infected lymphocytes may have been trapped in lymphoid organs and were not in the peripheral circulation. 3) The number of provirus particles may have been very low, and nested PCR would have been needed to increase the sensitivity. Any of these three possibilities would explain the absence of BLV provirus in BLV seropositive individuals because cross-reactivity had been ruled out.

In conclusion, the Northeastern Mexico area had a high prevalence of BLV. Evaluating if BLV can be considered a risk factor for human health is very important, especially in those individuals with potential occupational exposure. If $\mathrm{BLV}$ exposure is determined to be a risk factor for human disease, greater measures of occupational hygiene may be necessary.

\section{ACKNOWLEDGMENTS}

The publication of this study was supported by a research grant from the Programa Integral de Fortalecimiento Institucional (PIFI program).

\section{REFERENCES}

Altanerova V, Ban J, Kettmann R, Altaner C (1990). Induction of leukemia in chicken by bovine leukemia virus due to insertional mutagenesis. Arch Geschwulstforsch. 60:89-96.

Ballagi-Pordany A, Klintevall K, Merza M, Klingeborn B and Belak S (1992). Direct detection of bovine leukemia virus infection: practical applicability of a double polymerase chain reaction. Zentralbl Veterinarmed B. 39:69-77.
Buehring GC, Philpott SM, Choi KY (2003). Humans have antibodies reactive with Bovine leukemia virus. AIDS Res. Hum. Retroviruses 19:1105-1113.

Burny A, Bruck C, Cleuter $Y$ et al. (1985). Bovine leukemia virus a versatile agent with various pathogenic effects in various animal species. Cancer Res. 45:4578-4582.

Cereda PM, Debiaggi Mand Romero E (1984). Antibody to bovine leukemia virus in sera from leukemic patients. Microbiologica 7:107112.

Curtis AH, Kersey JH (1988). A modified method of DNA extraction from peripheral blood and bone marrow specimens. Am. J. Hemat. 28:176-180.

Ghysdael J, Bruck C, Kettmann R, Burny A (1984). Bovine leukemia virus. Curr. Top. Microbiol. Immunol. 112:1-19.

Hajj HE, Nasr R, Kfoury Y, Dassouki Z, Nasser R, Kchour G, Hermine $\mathrm{O}$, de Thé $\mathrm{H}$, Bazarbachi A (2012). Animal models on HTLV-1 and related viruses: what did we learn?. Front Microbiol. 3:333.

Johnson ES, Dalmas D, Noss J, Matanoski GM (1995). Cancer mortality among workers in abattoirs and meatpacking plants: an update. Am. J. Ind. Med. 27:389-403.

Johnson ES, Fischman HR, Matanoski GM, Diamond E (1986). Ocurrence of cancer in women in the meat industry. Br. J. Ind. Med. 43:597-604.

Johnson ES, Nicholson LG, Durack DT (1994). Poultry oncogenic retroviruses and humans. Cancer Det. Prev. 18:9-31.

Johnson ES, Nicholson LG, Durack DT (1995). Detection of antibodies to avian leucosis/sarcoma viruses (ALSV) and reticuloendotheliosis viruses (REV) in humans by ELISA. Cancer Det. Prev. 19:394-404.

Lee J, Kim Y, Kang CS, Cho DH, Shin DH, Yum YN, Oh JH, Kim SH, Hwang MS, Lim CJ, Yang KH, Han K (2005). Investigation of the bovine leukemia virus proviral DNA in human leukemias and lung cancers in Korea. J. Korean Med. Sci. 20:603-606.

Malivanova TF, Litvinov SV (1990). Antibodies to retroviruses of types C and $D$ in female patients with benign and malignant mammary tumours. Acta Virol. 34:19-26.

Maruyama K, Fukushima T, Mochizuki S (1989). Cross-reactive antibodies to BLV and HTLV in bovine and human host with retrovirus infection. Vet Immunol Immunopathol. 22: 265-273.

Meas S, Seto J, Sugimoto C, Bakhsh M, Riaz M, Sato T, Naeem K, Ohashi K, Onuma M(2000). Infection of bovine immunodeficiency virus and bovine leukemia virus in water buffalo and cattle populations in Pakistan. J. Vet. Med. Sci. 62:329-331.

Miller JM, Van Der Maaten MJ (1977). Use of glycoprotein antigen in immunodiffusion test for Bovine leukemia virus antibodies. Eur. J. Can. 13:1369-1375.

Murtaugh MP, Lin GF, Haggard DL, Weber AF, Meiske JC (1991). Detection of bovine leukemia virus in cattle by the polymerase chain reaction. J. Virol. Methods 33:73-85.

Nikbakht GH, Rabbani M, Emam M, Rezatofighi E (2010). Serological and genomic detection of bovine leukemia virus in human and cattle samples. Int. J. Vet. Res. 4: 253-258.

Onuma M, Wada M, Yasutomi Y, Yamamoto M, Okada HM, Kawakami 
$Y$ (1990). Suppression of immunological responses in rabbits experimentally infected with bovine leukemia virus. Vet. Microbiol. 25:131-141.

Rodríguez SM, Florins A, Gillet N, de Brogniez A, Sánchez-Alcaraz MT, Boxus M, Boulanger F, Gutiérrez G, Trono K, Alvarez I, Vagnoni L, Willems $L$ (2011). Preventive and therapeutic strategies for bovine leukemia virus: lessons for HTLV. Viruses 3:1210-48.

Sagata NT, Yasunaga J, Tsuzuku-Kawamura J, Ohishi K, Ogawa Y, Ikawa $Y(1985)$. Complete nucleotide sequence of the genome of Bovine Leukemia Virus: Its evolutionary relationship to other retroviruses. Proc. Natl. Acad. Sci. 82: 677-681.

Slavikova K, Kettmann R, Reinerova M, Zajac V, Portetelle D, Burny A (1987). Provirus integration of bovine leukemia virus into DNA of infected human myeloma cells. Neoplasma 34:653-657.
Wyatt CR, Wingett $D$, White JS, Buck CD, Knowles D, Reeves $R$ (1989). Persistent infection of rabbits with bovine leukemia virus associated with development of immune dysfunction. J. Virol. 63:4498-4506.

Zapata-Benavides P, Lara-Rodriguez MA, Alcocer-Gonzalez JM, Rodriguez-Padilla C, Tamez-Guerra R, Trejo-Avila LM (1996). Seroprevalence of HTLV-I/II in different groups at risk in northeast Mexico. Vox Sang. 70:181-182. 